\title{
HISTOLOGICAL DETECTION OF FASCIOLA LARVAL STAGE IN SNAILS IN SULAIMANI- KURDISTAN- IRAQ
}

TAHIR ABDULLAH HAWRAMI*; OTHMAN JAMAL NASSRULLAH ${ }^{* *}$; KARZAN SERWAN ABDULLAH $^{* * *}$; SIRWAN HAMA SHAREF QARADAQE*** and SIRWAN MUHSIN HAMA $\operatorname{AMIN}^{* * * * *}$

*University of Sulaimani/college of medicine

${ }^{* *}$ University of Sulaimani/college of medicine

${ }^{* * *}$ University of Sulaimani/college of veterinary medicine

${ }^{* * * *}$ Sulaimani Teaching hospital/GIT center

****** University of Sulaimani/college of science Kurdistan Region-Iraq

\section{ABSTRACT}

Received at:24/4/2013

Accepted: 1/6/2013
Background Fasciolosis is an economically important disease of domestic livestock, in particular cattle and sheep, and occasionally man. The disease is caused by digenean trematodes of the genus Fasciola, commonly referred to as liver flukes. The two species most commonly implicated as the aetiological agents of fasciolosis are F. hepatica and F. gigantica (family Fasciolidae). F. hepatica has a worldwide distribution but predominates in temperate zones while F. gigantica is found on most continents, primarily in tropical regions.

Aims: Record the snail that is considered as intermediate host of fasciola and determine the most infected area by the snail that is mean infected area by fasciola and facilitates the control in human and animal fasciolosis.

Method: A descriptive crossectional study was undertaken at eight different regions in Sulaimany governorate diagnosed as snail sampling area that includes Penjewen/ Chamigawra, Sharazoor/ SaidSadiq, Saraisubhanaga, Penjewen/ ChamiNzara, Penjewen/ Homarsenan, Penjewn/ Hajieliasafa, Penjewen/ Kanichawazar and Sharbazher/ Khewata. Histological study of the snail was performed by the routine histological technique (the positive area was $8.3 \%, 8.6 \%$ and $10 \%$ respectively in Penjewen/Chamigawra, Sharazoor/SaidSadiq and Saraisubhanaga snails other regions was negative).

Conclusion: This is a new appearance of the incidence of fasciola in Sulamani province and the reason may be due to the climate and environmental changes that enhance parasite survival.

Key words: Fasciola, Lymnaea, snail. gigentica

\section{INTRODUCTION}

Fascioliasis is caused by digenean trematodes related to genus Fasciola is a worldwide parasitic disease common in ruminants, especially cattle, buffaloes, sheep, goats, and swine. It may, however, affect humans (Marques and Scroferneker, 2003; Kelly et al., 2004). Great economical losses are believed to be caused by such parasitism, leading to the decrease of meat and milk production as well as to high mortality rates in several countries in the world (Saleha, 1991 and Mendes et al., 2008). The worldwide distribution of $F$. hepatica is related to climatic factors such as availability of humid habitats subject to flooding as well as the presence of definitive and especially intermediate hosts (Boray, 1969 and Dalton, 1999). The definitive host species in which the parasite develops plays an important role in determining the success of infection in the intermediate host (Vignoles et al., 2004). Definitive host species eliminate, viable eggs in their faeces and the development of miracidia which occurs in the environment. The miracidium must then penetrate into a susceptible snail, the intermediate host. In the snail tissues the larvae undergo some changes, to develop to rediae and later to cercariae. Soon after their emergence from the host, the cercaria changes to metacercaria. To complete the life cycle metacercariae must be ingested by definitive hosts. Fasciola intermediate host snails belong to the genus Lymnaea. Lymnaeidae are widely distributed in fresh water (hermaphrodite pulmonata with a dextral shell and without operculum). There are over 20 species of the genus and many of them are $F$. hepatica and $F$. gigantica transmitters. (Saleha, 1991; de Souza et al., 2002). Histological techniques have been widely employed to define the migratory routes of some parasites in their hosts and to study tissue alterations in snails due mainly to trematode infection (Kelly et al., 2008). In these histological studies, samples 
were usually fixed in formalin and embedded in paraffin. They were then histologically sectioned and stained with haematoxylin-eosin (HE). In developing countries little published information exists and data on the prevalence of helminthic infections, particularly on fascioliasis. Present study is the first one about detection of larval stage of liver fluke in the snail.

\section{MATERIALS and METHODS}

\section{Samples collection}

Between October and December 2007, one hundred and eighty-five samples were collected from eight different regions in Sulaimany governorate (100 being from Lymnaea sp., 45 from physa sp. and 40 from Gerolis sp.).

Table 1: number of samples obtained from different regions.

\begin{tabular}{lcccc}
\hline \multicolumn{1}{c}{ Regions name } & No.of samples & Lymnaea Sp. & physa sp. & Gerolis sp. \\
\hline 1- Penjewn/ChamiNzara & 17 & 12 & 4 & 1 \\
\hline 2- Penjewn/Kanichawazar & 25 & 8 & 7 & 10 \\
\hline 3- Penjewn/Homarsenan & 25 & 13 & 9 & 3 \\
\hline 4- Penjewn/Hajieliasafa & 20 & 7 & 4 & 9 \\
\hline 5- Penjewn/Chamigawra & 30 & 24 & 2 & 4 \\
\hline 6- SaidSadiq & 29 & 23 & 5 & 1 \\
\hline 7- Saraisubhanaga & 15 & 10 & 4 & 13 \\
\hline 8- Khewata & 24 & 9 & 2 & 42 \\
\hline Total & 185 & 106 & 37 & \\
\hline
\end{tabular}

\section{Histological procedure:}

The preparation of histological sections depended on standard methods of (Baker et al.,1975; Leeson and Leeson, 1981) as follow:

The snail organ (after removing shell) was cut into small pieces with morphological abnormalities and put in a small container contained $10 \%$ formal saline and kept for $12 \mathrm{hrs}$ for sample fixation.

The Specimens were dehydrated through a scending grades of more ethanol starting from $70 \%, 90 \%$, and $100 \%$ twice, $3 \mathrm{hrs}$ for each concentration and placed in xylene (most rapid clearing agent) for 2 hours. Specimens were thoroughly placed in the mixture of melted paraffin and xylene for 2 hours at $60^{\circ} \mathrm{C}$.

\section{Moulds for Embedding:}

The specimens were placed in a metal template filled with melted paraffin after embedded wax was solidified the paraffin blocks were removed from the metal and the individual paraffin blocks trimmed for preparing block with parallel sides.

\section{Sectioning (Cutting the section):}

This process was done by rotary microtome; the thickness was gauged at four microns, and then microtome operated until complete sections were again being cut and then maintained a regular cutting rhythm, and then the sections were affixed on slides.

\section{Mounting the sections on slides:}

Several slides should be cleaned, smeared with a drop of Mayer's egg albumin. Fixing the section on the slide by using a hot plate.
The slide was flooded with distilled water $55^{\circ} \mathrm{C}$, the sections were placed on the slide, ribbons of sections arranged on the slide and placed on hot plate, at $45^{\circ} \mathrm{C}$ in order to stretches the ribbon and removing all creases. When the sections are fully extended, the slides were removed from the hot plate, drain off excess water and afterwards the sections stained by haematoxylin-eosin (HE).

The sections examined by light microscope under magnification power 40X. Photographs taken by computerized microscope-camera (GKBCCD color digital camera).

\section{RESULTS}

\section{Percentage of larval stage:}

From total snail number 185 only 106 were Lymnea spp and from total Lymnea spp only 5 was infected fig1.A total of 106 Lymnaea sp were included in the present study. These include 10 from Penjewen/ChamiNzara, 10 Penjewen/Kanichawazar, 10 Penjewen/Homarsenan, 10 Penjewn/Hajieliasafa, 20 Penjewen/Chamigawra, 20 Sharazoor/SaidSadiq, 10 Sharazoor/Saraisubhanaga and 10 from Sharbazher/Khewata were analyzed for the presence of larval stages (Redia or Sporocyst) specific for Fasciola using Histological Technique, of which 2 (10\%) were Penjewen/Chamigawra, 1 (5\%) at Sharazoor/SaidSadiq, and 1 (10\%) Sharazoor/ Saraisubhanaga snails were infected with Fasciola. Overall infection rate was 4 (4\%) (Table 2). 


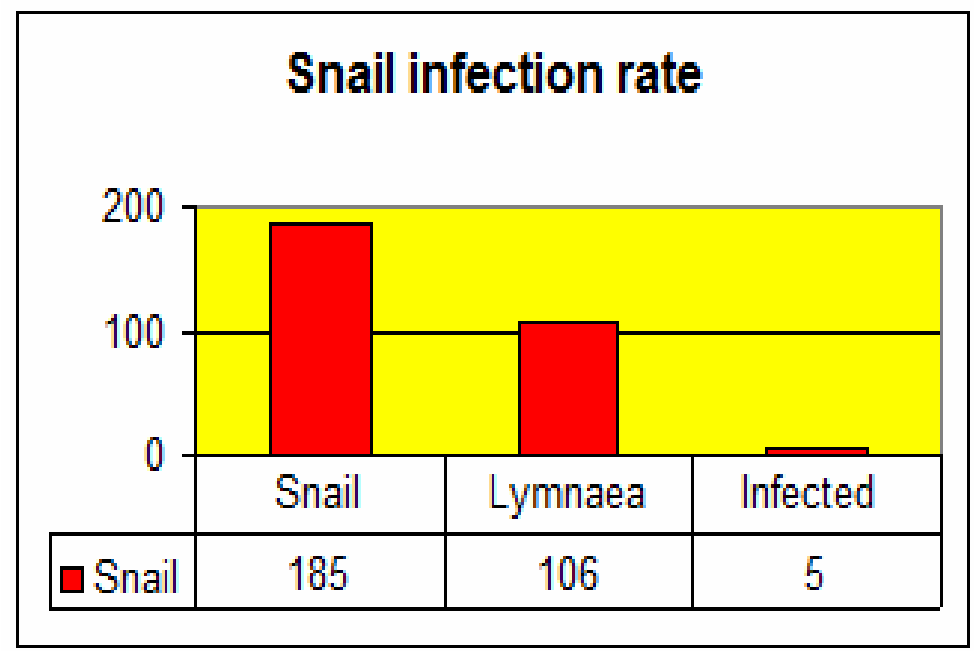

Fig.1 Snail infected rate

Table 2: Prevalence of fascioliasis in snails.

\begin{tabular}{cccc}
\hline Samples area & Lymnaea Sp. & Positive Snail & (\%)Percentage of Positive Snails \\
\hline Penjewen/ChamiNzara & 12 & - & 0 \\
\hline Penjewen/Kanichawazar & 8 & - & 0 \\
\hline Penjewen/Homarsenan & 13 & - & 0 \\
\hline Penjewen/Hajieliasafa & 7 & - & 0 \\
\hline Penjewen/Chamigawra & 24 & 2 & 8.3 \\
\hline Sharazoor/SaidSadiq & 23 & 2 & 8.6 \\
\hline Sharazoor/Saraisubhanaga & 10 & 1 & 0 \\
\hline Sharbazher/Khewata & 9 & - & 4.7 \\
\hline Total NO & 106 & 5 & \\
\hline
\end{tabular}

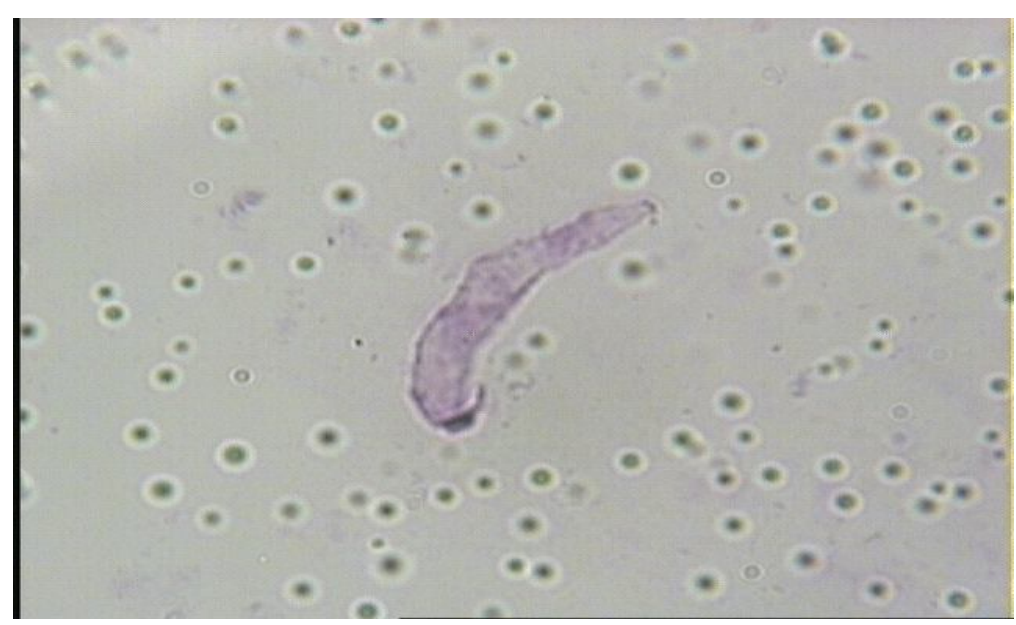

Fig.2: Histological slide HE stained, visualized by light microscopy showing Lymnaea sp. infected with redia.

Under light microscopy analysis, redias of Fasciola were found in the lumen of different segments of the digestive tract of Lymnaea sp. (Fig.2) The present study is the first of its record in this region. 


\section{DISCUSSION}

Though the overall prevalence of $4.0 \%$ in the intermediate host in different location as in (table,1) is similar to prevalences in other countries such as Algeria (4.0\%,), (Mekroud et al., 2004), France $(5.1 \%$ ), (Mage et al., 2002). or Spain (11.4\%,), (Manga-Gonzalez et al., 1991) there are clear differences of prevelances in populations from the different types and locations of habitats. In reeds, wells and spring swamps the risk for snails to get infected with $F$. hepatica is significantly higher than in streams. Reeds and spring swamps are typical L. truncatula habitats. Silted wells also make an ideal habitat for a stable population of L. truncatula. Snail populations in reeds, wells and spring swamps do not undergo as much fluctuation, as populations in streams. Therefore, the infection risk for each snail increases by time. Furthermore, miracidia will more easily find snails in stagnant than in flowing water. From this it can be concluded that the potential risk of infection for cattle grazing near to reeds, spring swamps or on pastures with silted wells is higher than alongside of streams.

The failure to detect any Fascola larval stage in histological slides through light microscopy was also reported by Hodasi (Hodasi, 1972) and Lessa (Lessa, 2001), who pointed out the difficulties to find parasite larval stages in digestive gland lobules during regular intervals. However, histological alterations in the tissue adjacent to the stomach, digestive and albumen glands were observed. Degeneration and necrosis in tissues were usually observed in Lymnaea $s p$. infected by Fasciola due to mechanic trauma as a consequence of parasite movements from the feet to the digestive gland of the snail (Hodasi, 1972; Patnaik, and Ray, 1966). When the sporocysts are young and located in the cephalopodal region, or when the snails are collected in the field and probably infected with different trematode (Loker et al., 1982), it is impossible to diagnose the trematode through those methods due to the similarity of young stages. Another difficulty arises when the snails collected in the field die before their arrival to laboratory, precluding any chance of trematode detection. Such remarks are quite important once the snails should be kept in laboratory and periodically observed, in order to obtain reliable results.

\section{ACKNOWLEDGMENT}

Thanks to histopathological department of Sulaimany teaching hospital for their help in sectioning and staining slides. Thanks to Awaz Salih Mahmood, Ala Aziz Hama and Shokhan Rahman Abdullah for their help in collecting samples.

\section{REFERENCES}

Marques, S.M.T. and Scroferneker, M.L. (2003): Fasciola hepatica infection in cattle and buffaloes in the State of Rio Grande do Sul, Brazil. Parasitol Latinoam 58: 169-172.

Kelly, G.M.; Liana, K.J-P. and Omar dos, S.C. (2004): Detection of Lymnaea columella Infection by Fasciola hepatica through Multiplex-PCR. Mem Inst Oswaldo Cruz, Rio de Janeiro, 99(4): 421-424.

Saleha, A.A. (1991): Liver fluke desease (fascioliasis): epidemiology economic impact and public health significance. Southeast Asian J. Trop Med Public Health 22 (Suppl.): 361-364.

Mendes, E.A.; Lima; W.S. and de Melo, A.L. (2008): Development of Fasciola hepatica in Lymnaea columella infected with miracidia derived from cattle and marmoset infections. Journal of Helminthology, 82: 81-84.

Boray, J.C. (1969): Experimental fascioliasis in Australia. Advances in Parasitology. 7: 95-210.

Dalton, J.P. (1999): Fasciolosis. New York, NY 10016. Printed and bound in the UK at the University Press, Cambridge. 119-120.

Vignoles, P.; Me'nard, A.; Rondelaud, D.; Agoulon, A. and Dreyfuss, G. (2004): Fasciola hepatica: the growth and larval productivity of redial generations in Galba truncatula subjected to miracidia differing in their mammalian origin. Journal of Parasitology 90, 430-433.

de Souza, C.P.; Magalhaes, K.G.; Passos, L.K.; Pereira dos Santos, G.C.; Ribeiro, F. and Katz, N. ( 2002): Aspects of the maintenance of the life cycle of Fasciola hepatica in Lymnaea columella in Minas Gerais. Brazil. Mem. Inst. Oswaldo Cruz. 97: 407-410.

Kelly, G.M.; Liana, K. J-P.; Roberta, L.C.; Maria, E.A.B.; Gertrude, M.; Omar dos S.C. and Henrique, L. L. (2008): Isolation and detection of Fasciola hepatica DNA in Lymnaea viatrix from formalin-fixed and paraffin-embedded tissues through multiplex-PCR. Veterinary Parasitology 152: 333-338.

Baker, F.J.; Silverton, R.E. and Luckcock, E.D. (1975): An introduction to medical laboratory technology. $4^{\text {th }}$ edition. Butterworths.

Leeson, T.S. and Leeson, C.R. (1981): Histology. W. B. Saunders. Company/ Philadelphia/ London/ Toronto.

Mekroud, A.; Benakhala, A.; Vignoles, P.; Rondelaud, D. and Dreyfuss, G. (2004): Preliminary studies on the prevalences of natural fasciolosis in cattle, sheep, and the host snail (Galba truncatula) in north-eastern Algeria, Parasitol. Res. 92: 502-505. 
Mage, H.; Bourgne, J.M.; Toullieu, D.; Rondelaud and Dreyfuss, G. (2002): Fasciola hepatica and Paramphistomum daubneyi: changes in prevalences of natural infections in cattle and in Lymnaea truncatula from central France over the past 12 years, Vet. Res. 33 (2002): $439-447$.

Manga-Gonzalez, Y.; Gonzalez-Lanza C.; and OteroMerino, C.B. (1991): Natural infection of Lymnaea truncatula by the liver fluke Fasciola hepatica in the Porma Basin, León 'NW Spain ، J. Helminthol. 65: 15-27.

Hodasi, J.K. (1972): The effects of Fasciola hepatica on Lymnaea truncatula. Parasitology 65: 359-369.

Lessa, C.S.S. (2001): Cronologia comparativa das leso es teciduais das formas larvais de Fasciola hepatica Linnaeus, 1758 em Lymnaea columella Say, 1817 em condic,ões experimentais. Tese de Mestrado, Departamento de Medicina Veterina'ria da Universidade Federal Rural do Rio de Janeiro.

Patnaik, M.M. and Ray, S.K. (1966): A histopathologic study of Lymnea auricularia var. rufescens infected with the larval stages of Echinostoma revolutum. Jpn. J. Med. Sci. Biol. 19: 253-258.

Loker, E.S.; Bayne, C.J.; Buckley, P.M. and Kruse, K.T. (1982): Ultrastructure of encapsulation of Schistosoma mansoni mother sporocysts by hemocytes of juveniles of the 10-R2 strain of Biomphalaria glabrata. J Parasitol 68: 84-94.

$$
\begin{aligned}
& \text { الكثف عن يرقات الفاشيولا في القواقع بمحافظة السليمانية ـ اكردستان ـ العراق } \\
& \text { طاهر عبد الله هورامى، عثمان جمال نصر الله ، كاززان سبروان عبد الله ، سيروان حمه شريف قرداغى } \\
& \text { سيروان محسن حمه امين كارن عيروان }
\end{aligned}
$$

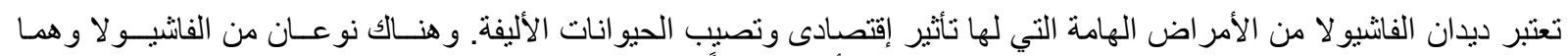
F. hepatica and F. gigantica

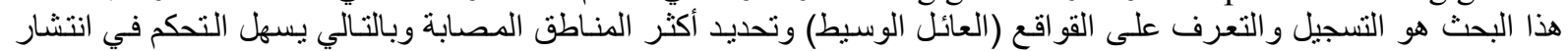

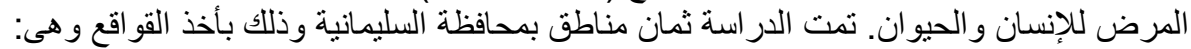

Penjewen / Chamigawra, Sharazoor /SaidSadiq, Saraiaubhanaga, penjewen /ChamiNzara, Penjewen /Homarsenan, Penjewn/Hajieliasfa,

استخلصت من هذه الدر استة أن ظهور الفاثيو لا في محافظة السليمانية تعزى إلى التغيرات البيئية و الحرارية التي قد تساعد على حياة 